\title{
Effects of Nandrolone Decanoate on Spermatogenesis in Wistar Rats With and Without Physical Training
}

\author{
Efectos del Decanoato de Nandrolona sobre la Espermatogénesis \\ en Ratas Wistar con y sin Entrenamiento Físico
}

\author{
Bernardo Porto Maia*; Jéssica de Oliveira Silveira*; Mariana Garcia Lisboa Borges*; Danilo Ales Ponzi Pereira*; \\ Julyara Lima Pinheiro"; Jofre Jacob da Silva Freitas ${ }^{* *}$ \& Katia Simone Kietzer**
} MAIA, B. P.; SILVEIRA, J. O.; BORGES, M. G. L.; PEREIRA, D. A. P.; PINHEIRO, J. L.; FREITAS, J. J. S. \& KIETZER, K. S.
Effects of nandrolone decanoate on spermatogenesis in Wistar rats with and without physical training. Int. J. Morphol., 33(3):1102-1107,
2015.

SUMMARY: Androgenic anabolic steroids (AAS) are artificial testosterone analogues, used as medicine in chronic diseases, because they increase protein synthesis generating muscle hypertrophy. Its effect has caught the attention of athletes and gym users, thus their consumption has become epidemic, due to easy marketing, the immediate results and the false impression that it doesn' $t$ carry health risks. Such risks may globally harm the body. This study aims to investigate the influence on spermatogenesis of using nandrolone decanoate with or without physical training. Twenty-four rats, divided into four groups were used: sedentary group (SG), sedentary on steroids group (SSG), trained group (TG) and trained on steroids group (TSG). The animals were trained on voluntary exercise wheel twice a week during 12 weeks, and were subsequently euthanized by decapitation. Groups TSG and SSG received intramuscular injections of $5 \mathrm{mg} / \mathrm{kg}$ of the AAS. It was found that there was a greater cellularity in TSG, suggesting interference between androgen therapy and physical training on the mount of cells in the seminiferous epithelium. Comparing the TSG group with the SG, it is noticed that the physical training associated with the use of steroid tends to affect cell division without compromise, however, the number of spermatogonia, did not significantly vary compared to the control group. Finally, it seems that there was no significant statistical difference among the groups in terms of spermatogenesis yield, so that can not be said that the use of nandrolone decanoate, with or without the physical training, interfere with fertility.

KEY WORDS: Spermatogenesis; Anabolic agents; Nandrolone ; Exercise; Fertility.

\section{INTRODUCTION}

Androgenic anabolic steroids (AAS) are artificial testosterone analogues, produced by testicles (90\%) and adrenal glands (10\%). They are responsible for male characteristics development (androgyny) and for the lean tissue synthesis (anabolism), being used as medicine in chronic diseases, because they increase protein synthesis generating muscle hypertrophy (Kang et al., 2014; Koike, 2010; Smith \& Walker, 2014).

Due to the remarkable anabolic effect, mainly in muscle tissue, the AAS are being widely used by individuals to improve their athletic performance or bodily appearance. Besides the hypertrophy of skeletal muscle mass, these substances also promote androgenization, stimulating masculinizing characteristics in both men and women (Boff, 2010; de Paiva Foletto et al., 2010).
Nandrolone decanoate (ND), also known as DecaDurabolin ${ }^{\circledR}$ and developed by Organon Laboratory in 1962, presents characteristic of being more anabolic than androgenic, which is why it became one of the most used AAS in the world (Oliveira et al., 2012). It is also one of the most used AAS in gyms for beauty purposes (de Paiva Foletto et al.) and it is widely used in the clinical medicine (Oliveira et al.).

Among the many side effects of hormonal therapy with AAS, are: heart problems, disorders of the adrenal glands, aggressive behavior, increased risk of prostate cancer, problems related to a lack of libido and impotence.

Beside its influence on the prostate and libido, AAS seems to directly affect the testicles and their functions. It is known that several species of experimental animals evolved

\footnotetext{
* Universidade do Estado do Pará, Belem, Brazil.

** Laboratório de Morfofisiologia Aplicada a Saúde, Universidade do Estado do Pará, Belem, Brazil.
} 
with decreased testicular size and weight, after AAS treatment. These two factors may inhibit the luteinizing hormone and diminish levels of endogenous testosterone, probably impairing the spermatogenesis (de Paiva Foletto et al.). The use of ND, combined or not with physical training, resulted in the development of epithelial hyperplasia, in an increase of the stroma in lateral and ventral lobe of the prostate, and in the lumen increase in the dorsal lobe of prostate of adult rats (Karbalay-Doust \& Noorafshan, 2006; de Paiva Foletto et al; Scudeler et al., 2009).

Despite all the information commented above, the studies that evaluated the effects of AAS on the reproductive system are scarce, especially about ND. Thus, this study aims to investigate the influence on spermatogenesis of using ND with or without physical training.

\section{MATERIAL AND METHOD}

This is a prospective, randomized, cohort, longitudinal, local, descriptive statistical study, which examined the effects of anabolic androgenic steroid (AAS), nandrolone decanoate (ND), on the spermatogenesis of healthy male adult Wistar rats submitted or not to physical training.

We used 24 Rattus novergicus from Wistar lineage. The animals were divided into four groups with 6 animals each: sedentary group (SG), which is the control group, sedentary on steroids group (SSG), trained group (TG), and trained on steroids group (TSG).

Animals in the TSG and TG were placed in a voluntary wheel, where they remained for 6 hours per day. This procedure was performed twice a week and continued for 12 weeks, when the rats were euthanized by decapitation.

Animals in the TSG and SSG received intramuscular injections, twice per week, in the quadriceps muscles using insulin syringe containing $5 \mathrm{mg} / \mathrm{kg}$ of ND diluted in mineral oil. According to Norton et al. (2000), this dose has been reported as equivalent to the doses normally used by athletes in gyms.

After 12 weeks of training and AAS treatment, animals were euthanized by decapitation. The testicles were removed by median longitudinal laparotomy. The testicles were then prepared from histological techniques, fixed in formol $10 \%$, imbibed in paraffin, and 10 cross sections, of 5 $\mu \mathrm{m}$ thick each, were obtained by Leika microtome, from each animal's material. Histological slides were colored by hematoxylin and eosin technique. The histomorphological analysis occurred by Zeiss microscope with a Progress 300 digital color camera and a KS400 image analyzer, that did the quantification of the cell types (Spermatogonia A, Spermatocyte I, Spermatid and Sustentocytes Sustentocytes), and obtaining spermatogenesis yield, using the Abercrombie (1946) formula modified by Amann (1962), quoted by Sarti (2006), de Paiva Foletto et al. and Costa et al. (2004).

The experiment data were recorded in research protocols and organized in a database. During the descriptive statistics, all values were presented as mean and standard deviation. The numerical data were analyzed by the D'Agostino - Pearson's test and subsequently inferential statistical analysis (comparative) by ANOVA test (analysis of variance) was carried out when the distribution was normal; or by KruskalWallis test for non-normal distributions. Both tests were nonpaired and two-tailed. In all tests, the rejection rate was fixed at $0.05(\mathrm{p}<0.05)$. Microsoft Excel ${ }^{\circledR}$ was used for descriptive statistics and BioEstat 5.3® for inferential statistics.

\section{RESULTS}

The population of different cell types in stage 1 of the seminiferous epithelium cycle of Wistar rats from the experimental groups studied is shown in Figure 1 and Table I. Table II shown the comparison between the experimental groups according to the cell type.

Yield of spermatogenesis in rats of the groups were shown in Figure 2 and Table III; also the efficiency and yield of spermatogenesis between groups (Table IV).

Table I. Population of different cell types in stage 1 of the seminiferous epithelium cycle of Wistar rats from the experimental groups studied, Brazil, 2014.

\begin{tabular}{lcccccccc}
\hline \multirow{2}{*}{ Cell type } & \multicolumn{2}{c}{ TSG } & \multicolumn{2}{c}{ SSG } & \multicolumn{2}{c}{ TG } & \multicolumn{2}{c}{ SG } \\
\cline { 2 - 9 } & Mean & SD & Mean & SD & Mean & SD & Mean & SD \\
\hline Spermatogonia A & 35,55 & 13,19 & 28,02 & 11,26 & 33,82 & 10,97 & 30,68 & 10,04 \\
Spermatocyte I & 48,97 & 11,06 & 41,02 & 7,96 & 41,23 & 11,89 & 38,95 & 10,16 \\
Spermatid & 134,58 & 36,45 & 111,35 & 19,98 & 120,57 & 28,90 & 119,75 & 29,35 \\
Sustentocytes & 21,83 & 6,74 & 19,38 & 4,29 & 18,95 & 5,23 & 18,60 & 3,37
\end{tabular}




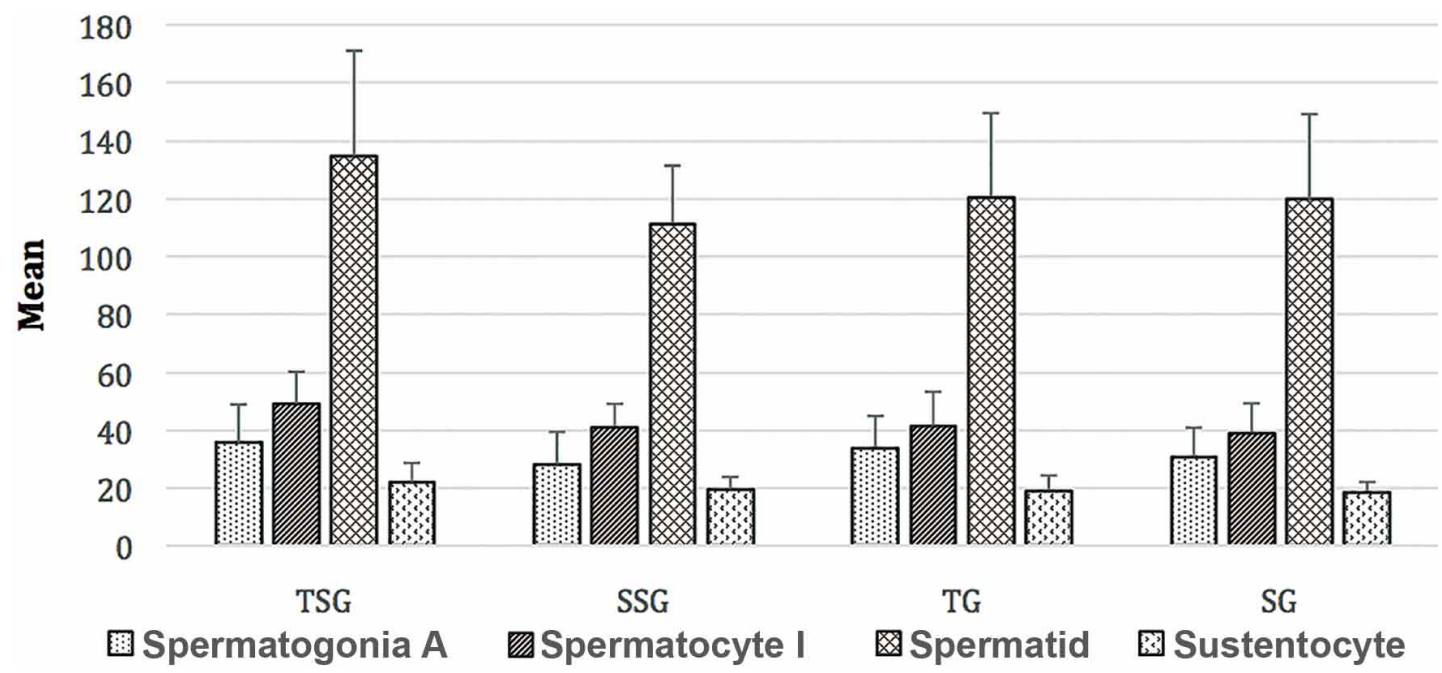

Fig. 1. Population of different cell types in stage 1 of the seminiferous epithelium cycle of Wistar rats from the experimental groups studied, Brazil, 2014.

\section{Mitosis Efficiency}

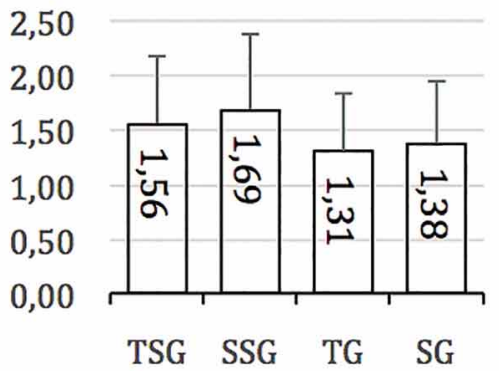

Meiotic Yield

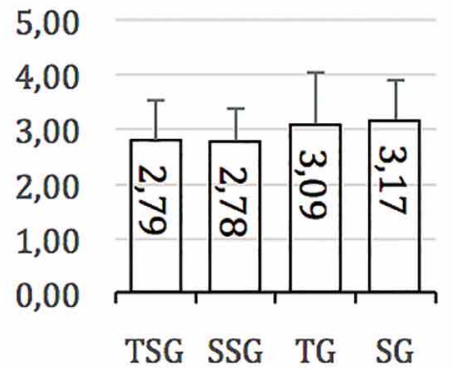

\section{General Yield}

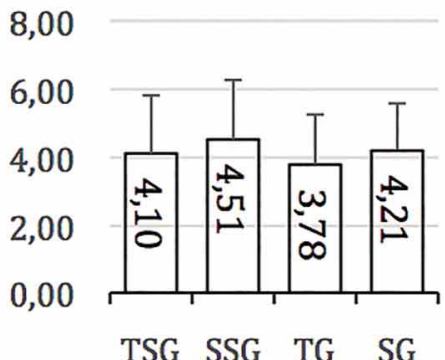

Fig. 2. Yield of spermatogenesis in rats from the experimental groups studied, Brazil, in 2014.

Table II. p value resulting from the comparison between the experimental groups according to the cell type of Wistar rats. Source: Research protocol.

\begin{tabular}{lcccc}
\hline Compared groups & Spermatogonia & Spermatocytes I & Spermatid & Sustentocytes \\
\hline TSG x SSG & $<0.01$ & $<0.05$ & $<0.05$ & $\mathrm{~ns}$ \\
TSG x TG & $\mathrm{ns}$ & $<0.05$ & $\mathrm{~ns}$ & $\mathrm{~ns}$ \\
TSG x SG & $\mathrm{ns}$ & $<0.05$ & $<0.05$ & $<0.05$ \\
SSG x TG & $<0.05$ & $\mathrm{~ns}$ & $\mathrm{~ns}$ & $\mathrm{~ns}$ \\
SSG x SG & $\mathrm{ns}$ & $\mathrm{ns}$ & $\mathrm{ns}$ & $\mathrm{ns}$ \\
TG x SG & $\mathrm{ns}$ & $\mathrm{ns}$ & $\mathrm{ns}$ & $\mathrm{ns}$ \\
\hline
\end{tabular}

Table III. Yield of spermatogenesis in rats from the experimental groups studied, Brazil, in 2014. Source: Research protocol.

\begin{tabular}{lcccccc}
\hline $\begin{array}{l}\text { Experimental } \\
\text { Groups }\end{array}$ & \multicolumn{2}{c}{$\begin{array}{c}\text { Spermatogonial } \\
\text { Mitosis efficiency }\end{array}$} & \multicolumn{2}{c}{$\begin{array}{c}\text { Meiotic } \\
\text { Yield }\end{array}$} & \multicolumn{2}{c}{$\begin{array}{c}\text { General } \\
\text { Yeild }\end{array}$} \\
\cline { 2 - 7 } & Mean & SD & Mean & SD & Mean & SD \\
\hline TSG & 1,56 & 1,56 & 0,62 & 2,79 & 0,73 & 4,10 \\
SSG & 1,69 & 1,69 & 0,69 & 2,78 & 0,59 & 4,15 \\
TG & 1,31 & 1,31 & 0,53 & 3,09 & 0,95 & 3,78 \\
SG & 1,39 & 1,39 & 0,57 & 3,17 & 0,73 & 4,21 \\
\hline
\end{tabular}


Table IV. p value resulting from the comparison among the experimental groups according to the efficiency and yield of spermatogenesis in male Wistar rats.

\begin{tabular}{lccc}
\hline Compared groups & $\begin{array}{c}\text { Spermatogonial } \\
\text { Mitosis efficiency }\end{array}$ & $\begin{array}{c}\text { Meiotic } \\
\text { yield }\end{array}$ & $\begin{array}{c}\text { General } \\
\text { yield }\end{array}$ \\
\hline TSG x SSG & $\mathrm{ns}$ & $\mathrm{ns}$ & $\mathrm{ns}$ \\
TSG x TG & $<0.05$ & $\mathrm{~ns}$ & $\mathrm{~ns}$ \\
TSG x SG & $\mathrm{ns}$ & $<0.05$ & $\mathrm{~ns}$ \\
SSG x TG & $<0.05$ & $<0.05$ & $\mathrm{~ns}$ \\
SSG x SG & $\mathrm{ns}$ & $<0.05$ & $\mathrm{~ns}$ \\
TG x SG & $\mathrm{ns}$ & $\mathrm{ns}$ & $\mathrm{ns}$ \\
\hline *p (Kruskal-Wallis) $=0.2167$. Source: Research protocol. & &
\end{tabular}

\section{DISCUSSION}

As shown in Table I, there was a greater cellularity in trained on steroid group (TSG), suggesting interference between androgen therapy and physical training on the mount of cells in the seminiferous epithelium. That result is similar to the data presented by de Paiva Folleto, who also found that the germ cells amount at stage 1 of the germinate cycle of seminiferous epithelium of rats in TSG was also greater when compared with the other groups. However, the author did not observe significant statistical differences between the spermatogonia population and Sustentocytes among the different groups of animals, therefore, the difference of the total number of germ cells in the TSG is related with the increase of primary spermatocytes and spermatids in this group.

In the present study, the predominance of cellularity in the TSG happened globally, in all cell types, which suggests the influence of the androgenic steroid in both mitotic phase and spermatogenic meiosis. That result is reinforced by O'Shaughnessy's study (2014) that reveals the activity of the androgenic hormones in both meiotic and mitotic process. On meiosis, the steroid decreased the apoptosis and guaranteed the survival of a bigger number of primary spermatocytes. On mitosis, it had a direct effect on the proliferation of spermatogonia A, which mechanism is not well specified.

Table II provides a comparison among the experimental groups according to cell types analyzed. Comparing the TSG group with the sedentary group (SG), it is noticed that the physical training associated with the use of steroid tends to affect cell division without however, compromising the number of spermatogonia, which did not significantly vary compared to the control group.

It is observed that, in the TSG group, the combination of nandrolone decanoate (ND) to physical activity significantly affected the primary spermatocytes, regardless the comparison made among the other groups. de Paiva Foletto et al., also testified predominance in primary spermatocytes count on TSG compared to all other groups of this study, supporting the hypothesis of combined steroid action with the exercise over this specific cell type.

Comparing TSG and SG, there was a significant variation of all studied cell types, except type A spermatogonias. It suggests that the use of steroid combined with the physical exercise does not interfere on the population number of this specific cell type.

Sustentocytes were not affected, when compared TSG and sedentary on steroids group (SSG). It means that a combination of steroid and exercise is necessary to affect the non-germ cells. The number of the other cell types seems to increase with just the isolated use of ND.

Spermatogonias, spermatocytes and spermatids showed a significant statistical difference between TSG and sedentary on steroids group SSG, being always higher in the TSG, implying thereby that the association of anabolic therapy with exercise increases the modifications on the population of germ cells.

The isolated action of ND on the cell population of the seminiferous epithelium translates from comparing SSG with the other experimental groups. When compared to the control group, there was no statistical difference between SG and SSG, implying that the steroid alone does not affect cellularity; on the other hand, the SSG was the group that presented a smaller number of cells.

The comparison between SSG and the trained group (TG) reveals more spermatogonias inTG, suggesting a possible inverse effect between the use of steroid and the practice of physical exercise on the number of this cell type, there is, therefore, reduction on espermatogonia number by the anabolic and increasing them with physical exercise. Takashiba 
et al. (2011) agree with this result since they found a positive effect of exercise on spermatogonia A count in their study.

The isolated effects of exercise are reflected by comparing the TG x SG groups, and it did not show any significant statistical difference between the TG and the control group. Thus, like the isolated use of anabolic substance, physical exercise alone does not represent any interference on the population of cells, germ or not, in the seminiferous epithelium.

Table III shows the yield of spermatogenesis for each experimental group. The SSG group had the best mitotic income, and the highest yield of the spermatogenic process as a whole. However, the meiotic yield was higher in the control group. de Paiva Foletto et al., have opposite result, where the SSG had further loss of cells during the mitotic process, reflecting the worst overall spermatogenic yield among the other experimental groups of the study.

Table IV provides comparisons about the yield among the four groups. The meiotic yield was significantly lower in SSG and TSG groups when compared to the SG group, which calls attention to a possible inhibition action of steroid on meiosis. This data is also opposed to that found by de Paiva Foletto et al., who found no difference in meiotic yield in the groups treated or not with ND or among those receiving or not physical training.

When comparing the same two groups (SSG and TSG) to the TG, it is observed that both showed higher mitosis efficiency than the TG group, confirming the direct action of androgenic substances over spermatogonias and suggesting, through the relationship TSG x TG, that the use of androgenic anabolic steroids, the only distinct variable between the two groups, is the real responsible for the reduction of mitotic efficiency, not representing, therefore, exercise an important role against the mitotic yield of spermatogenic process (O'Shaughnessy).

However, Takashiba et al., in a similar study but without use of anabolic steroids, found positive interference of physical training of rats in both meiotic and mitotic income, as in spermatogenesis yield. The discrepancy in the results probably happened because the differences between both studies, specially related with the training protocol, which in Takashiba et al., research occurred on a treadmill, with time and training speed controlled by the researcher, while in the present study the aerobic physical activity was on a voluntary wheel.

In conclusion, it seems that there was no significant impact of using ND, combined or not with physical training, on the spermatogenesis yield of Wistar rats. However, it was realized that the combination of AAS on physical activity induced higher cellularity, increasing all cell types studied. In addition, there was direct action of ND on meiotic yield, reducing it regardless physical training. The exercise, on the other hand, reduced the efficiency of spermatogonial mitosis, also regardless using or not steroids. Therefore, it is suggested that hormone therapy with ND (Deca Durabolin-Organon) can cause deleterious effects on spermatogenesis, although more research is necessary in order to obtain a long-term evaluation.

\section{ACKNOWLEDGMENTS}

We thank the National Council for Scientific and Technological Development $(\mathrm{CNPq})$ for sponsoring this study and Victor A. G. Coutinho by technical support in statistical analysis. We also thank the University of the State of Pará (UEPA) and the Laboratory of Morphophysiology Applied on Health for the opportunity.

MAIA, B. P.; SILVEIRA, J. O.; BORGES, M. G. L.; PEREIRA, D. A. P.; PINHEIRO, J. L.; FREITAS, J. J. S. \& KIETZER, K. S. Efectos del decanoato de nandrolona sobre la espermatogénesis en ratas Wistar con y sin entrenamiento físico. Int. J. Morphol., 33(3):1093-1101, 2015.

RESUMEN: Los esteroides anabólicos androgénicos (EAA) son análogos de testosterona artificiales, utilizados como medicina en las enfermedades crónicas, ya que aumentan la síntesis de proteínas generando hipertrofia muscular. Su efecto ha llamado la atención de atletas y usuarios de gimnasios, por lo que su consumo se ha convertido en epidemia, debido a la comercialización fácil, los resultados inmediatos y la falsa impresión de que no conllevan riesgos para la salud. Este estudio tiene como objetivo investigar la influencia de utilizar decanoato de nandrolona con o sin entrenamiento físico sobre la espermatogénesis. Se utilizaron 24 ratas, divididas en cuatro grupos: entrenado (GE), entrenado en esteroides (GEE), sedentario en esteroides (GSE) y sedentario (GS). Los grupos GEE y GSE recibieron inyecciones intramusculares de $5 \mathrm{mg} / \mathrm{kg}$ de la EAA. Los animales fueron entrenados con ejercicio voluntario en la rueda de correr dos veces por semana durante 12 semanas. Luego, los animales fueron sacrificados por decapitación. Se encontró que hubo una mayor celularidad en GEE, lo que sugiere la interferencia entre la terapia con andrógenos y entrenamiento físico en la cantidad de células en el epitelio seminífero. Comparando el grupo GEE con el GS, se observa que el entrenamiento físico asociado con el uso de esteroides tiende a afectar a la división celular sin comprometerla, sin embargo, el número de espermatogonias, no varió significativamente en comparación con el grupo control. Finalmente, no hubo diferencia significativa entre los grupos en términos de rendimiento de la espermatogénesis, por lo que no se puede decir que el uso del decanoato de nandrolona, con o sin el entrenamiento físico, interfiere con la fertilidad.

PALABRAS CLAVE: Espermatogénesis; Anabolizantes; Nandrolona; Ejercicio; Fertilidad. 


\section{REFERENCES}

Abercrombie, M. Estimation of nuclear population from microtome sections. Anat. Rec., 94(2):239-47, 1946.

Amann, R. P. Reproductive capacity of dairy bulls. IV. Reproductive capacity of dairy bulls. IV. Spermatogenesis and testicular germ cell degeneration. Am. J. Anat., 110(1):69-78, 1962.

Boff, S. R. Esteróides anabólicos e exercício: ação e efeitos colaterais. Rev. Bras. Cienc. Mov., 18(1):81-8, 2010.

Costa, D. S.; Henry, M. \& Paula, T. A. R. Espermatogênese de catetos (Tayassu tajacu). Arq. Bras. Med. Vet. Zootec., 56(1):46-51, 2004.

de Paiva Foletto, M.; Mareze-Costa, C.; Ferrari, F.; Franzói- deMoraes, S. \& Mara Segatelli, T. Effect of the nandrolone decanoate on the efficiency of spermatogenesis of sedentary rats and rats subjected to physical training. Acta Scientiarum Health Sci., 32(1):17-22, 2010.

Kang, H. J.; Moon, M. J.; Lee, H. Y. \& Han, S. W. Testosterone alters testis function through regulation of piRNA expression in rats. Mol. Biol. Rep., 41(10):6729-35, 2014.

Karbalay-Doust, S. \& Noorafshan, A. Stereological study of the effects of nandrolone decanoate on the rat prostate. Micron, 37(7):617-23, 2006.

Koike, D.C. Efeitos do treinamento físico no balanço autonômico e parâmetros cardiovasculares de ratos submetidos ao uso de esteróides anabólicos. Tese Mestrado em Educação Física. São Paulo, Universidade São Judas Tadeu, 2009.

Norton, G. R.; Trifunovic, B. \& Woodiwiss, A. J. Attenuated betaadrenoceptor-mediated cardiac contractile responses following androgenic steroid administration to sedentary rats. Eur. J. Appl. Physiol., 81(4):310-6, 2000.

Oliveira, R. L.; Antunes, M. M.; Iwanaga, C. C.; Moura, D. L. \& Torres, M. S. O esteróide anabolizante Deca-Durabolin: utilização, efeitos e legislação. EFDeportes.com Rev. Digit., 17(175), 2012. Available from: http://www.efdeportes.com/ efd175/o-esteroide-anabolizante-deca-durabolin.htm.

O’Shaughnessy, P. J. Hormonal control of germ cell development and spermatogenesis. Semin. Cell Dev. Biol., 29:55-65, 2014.

Sarti, P. Avaliação morfométrica do testículo e da espermatogênese de jaguatiricas Leopardus pardalis, Linnaeus, 1758) adultas. Tese Magister em Medicina Veterinária. Minas Gerais, Universidade Federal de Viçosa, 2006.

Scudeler, D. N. Estudo estereológico dos efeitos do decanoato de Nandrolona e do exercício físico sobre a próstata de Ratos adultos. Congresso. São Paulo, XXI Congresso de Iniciação Científica da UNESP, 2009.
Smith, L. B. \& Walker, W. H. The regulation of spermatogenesis by androgens. Semin. Cell Dev. Biol., 30:2-13, 2014.

Takashiba, K. S.; Segatelli, T. M.; de Moraes, S. M. F. \& Natali, M. R. M. Morfologia testicular de ratos Wistar obesos sedentários e submetidos a treinamento físico. Acta Scientiarum Health Sci., 33(1):25-33, 2011.

\author{
Correspondence to: \\ Bernardo Porto Maia \\ Universidade do Estado do Pará \\ Belem, Pará \\ BRAZIL
}

Email: bernardo_pmaia@hotmail.com

Received: 17-12-2014

Accepted: 29-05-2015 